\title{
A COPROLOGICAL SURVEY OF DONKEY PARASITES IN GHARBIA PROVINCE, EGYPT
}

Yasser M. Ghanem ${ }^{1}$, Moustafa A. Al- Araby ${ }^{2}$ and Medhat N. Nasef

1- Department of Animal Medicine (Infectious Diseases), Faculty of Veterinary Medicine, Kafrelsheikh University, Kafrelsheikh, 33516, Egypt.

2- Department of Parasitology, Faculty of Veterinary Medicine, Mansoura University, Egypt.

3- Department of Animal Medicine (Internal Medicine), Faculty of Veterinary Medicine, Kafrelsheikh University, Kafrelsheikh, Egypt.

\section{ABSTRACT}

The present study was conducted during the period from January to July 2010 at Elmehala Elkubra surrounding villages of Gharbia province where living conditions are rural communities. A total of 236 (132 male and 104 female) donkeys were randomly selected from rural places and subjected to qualitative coprological examinations to identify the major parasites involved in parasitic burden. Donkeys were grouped in to two age categories (under two years of age were classed as young and of two to ten years were classed as adult. Comparisons between age groups and sexes were made for donkeys. The parasites encountered in donkeys had a total prevalence of $82.21 \%$ (194/236). Single infection was $54.13 \%$ (105/194) while mixed infection was 45.87\% (89/194). Nematodes had highest prevalence $69.92 \%$ (165/236). Strongyles were more prevalent $34.75 \%$ (82/236), followed by Parascaris equorum 15.26\% (36/236), Oxyuris equi 
12.29\% (29/236), Dictycaulus spp. 5.94\% (14/236) and Habronema spp. $1.7 \%$ (4/236) respectively. Cestodes as Anoplocephala spp. was detected in (13/236) 5.51\% while trematodes as Gastrodiscus spp. in (9/236) $3.82 \%$ and Fasciola spp in (7/236) $2.97 \%$ respectively. According to sex of studied donkeys, females had higher prevalence $51.28 \%$ (121/236) than males $30.94 \%$ (73/236) and according to age, the prevalence in younger (up to 2 years) was lower $33.05 \%$ (78/236) while in adult donkeys (2-10 years) had higher 49.16\% (116/236). Recommendations were given.

Key Words: Donkeys, Gastrointestinal nematodes, Fecal examinations.

\section{INTRODUCTION}

Despite the increase in mechanization throughout the world, donkeys are still well deserving of the name 'beasts of burden'. This is shown by the wide spread use of donkeys in rural and urban areas in Africa (Pearson et al., 1999). They have a prominent position in the agricultural systems of many developing countries and engaged in income-generating activities (Marshall and Ali, 2004). The low level of development of the road transport network and the rough terrain of the country make the donkey the most valuable, appropriate and affordable pack animals under the small holder farming system of Ethiopia (GebreWold, et al., 2004).

Many authors investigated parasites affecting donkeys in Africa and worldwide. El-Seify, et al., (2010) in Egypt, Getachew et al., (2010) in Ethiopia; Seri et al., (2000) Khartoum State in Sudan; Matthee et al., (2000) in South Africa; Hasslinger and El-Seify (1996) in Egypt, 
Hasslinger, et al., (1996), Pandey et al., (1992) in Morocco; Ricci and Sabatini; (1992) in Italy; El-Seify, et al., (1991) in Egypt, Eysker and Pandey, (1989) in the Zimbabwean high field; Vercruysse et al., (1986), in Burkina Faso, El-Seify, et al., (1985) in Egypt.

The attention given by Governmental and non-Governmental organizations to donkeys has been far below to what it deserves. This might be partly due to the wrong perception that the donkey does not require a lot of care, that when donkeys do get sick they are quick to die, and the donkey's low traditional status (Marshall and Ali, 2004). Despite the considerable numbers and the neglected importance of donkeys in the Egyptian economy, knowledge about the health problems affecting their welfare is unknown as far as we know for most parts of the country. Therefore, the objectives of this study were to determine spectrum of species and prevalence of major parasites involved in donkeys from a rural area of Elmehala Elkubra surrounding villages of Gharbia Province.

\section{MATERIALS AND METHODS}

\section{Study Area:}

The present study was conducted during the period from January 2010 to August 2010 at Elmehala Elkubra surrounding villages of Gharbia Prpvince. The daily temperature ranged between $20^{\circ} \mathrm{C}$ and $40^{\circ} \mathrm{C}$ during that period. 


\section{Study animals and protocol:}

A total of 236 (132 male and 104 female) donkeys, were randomly selected and subjected to qualitative coprological examinations to identify the major parasites involved in parasites burden. Donkeys were grouped in to two age categories. Under two years of age were classed as young $(n=78)$, and adults from two to 10 years of age (116). Comparisons between age groups and sexes were made for donkeys.

\section{Fecal samples:}

Fecal samples were examined individually for GI nematode, cestodes, and fluke's eggs as well as protozoan cysts, trophozoites and oocysts. Fecal samples were taken directly from the rectum or the ground when donkeys were seen defecating in air and water tight sample vials, then brought to the laboratory of the Parasitology Department of the Faculty of Veterinary Medicine of Mansoura University without preservation within 1-2 hours after collection and kept at $4{ }^{\circ} \mathrm{C}$ until processing. However the history of these animals was not known

\section{Parasitological procedure:}

The fecal samples were carefully examined microscopically using the $10 \times$ objective. All parasites were identified using the keys of Yamaguti, (1959) and Soulsby, (1982). Sedimentation and floatation techniques were used for detection of parasitic stages (Urquhart et al., 1996; Soulsby, 1982). Floatation technique was performed using saturated sodium chloride solution (Willis, 1921). 


\section{RESULTS}

The total prevalence of parasites of donkeys was $82.21 \%(194 / 236)$. Nematodes had highest prevalence 69.92\% (165/236). Strongylus spp. was the most common species $34.75 \%$ (82/236), followed by Parascaris equorum 15.26\% (36/236), Oxyuris spp. 12.29\% (29/236), Dictycaulus spp. 5.94\% (14/236) and Habronema spp.1.70\% (4/236) respectively. Cestodes as Anoplocephala spp. 5.51\% (13/236) while trematodes as Gastrophilus spp. 3.82\% (9/236) and Fasciola spp 2.97\% (7/236) were identified (Table 1). Female animals had higher prevalence 51.28\% (121/236) while males had lower prevalence 30.94\% (73/236) (Table 2). The prevalence in younger (up to 2 years) was lower $33.05 \%(78 / 236)$ than adult donkeys from 2-10 years 49.16\% (116/236) (Table 3). Single infection and mixed infection analysis has revealed that (105/236) $54.13 \%$ of donkeys, were infected by a single parasite and (89/236) $45.78 \%$ of them were harboring more than one parasite species (Table 4). Photo taken for identified eggs are illustrated in figure 1. 


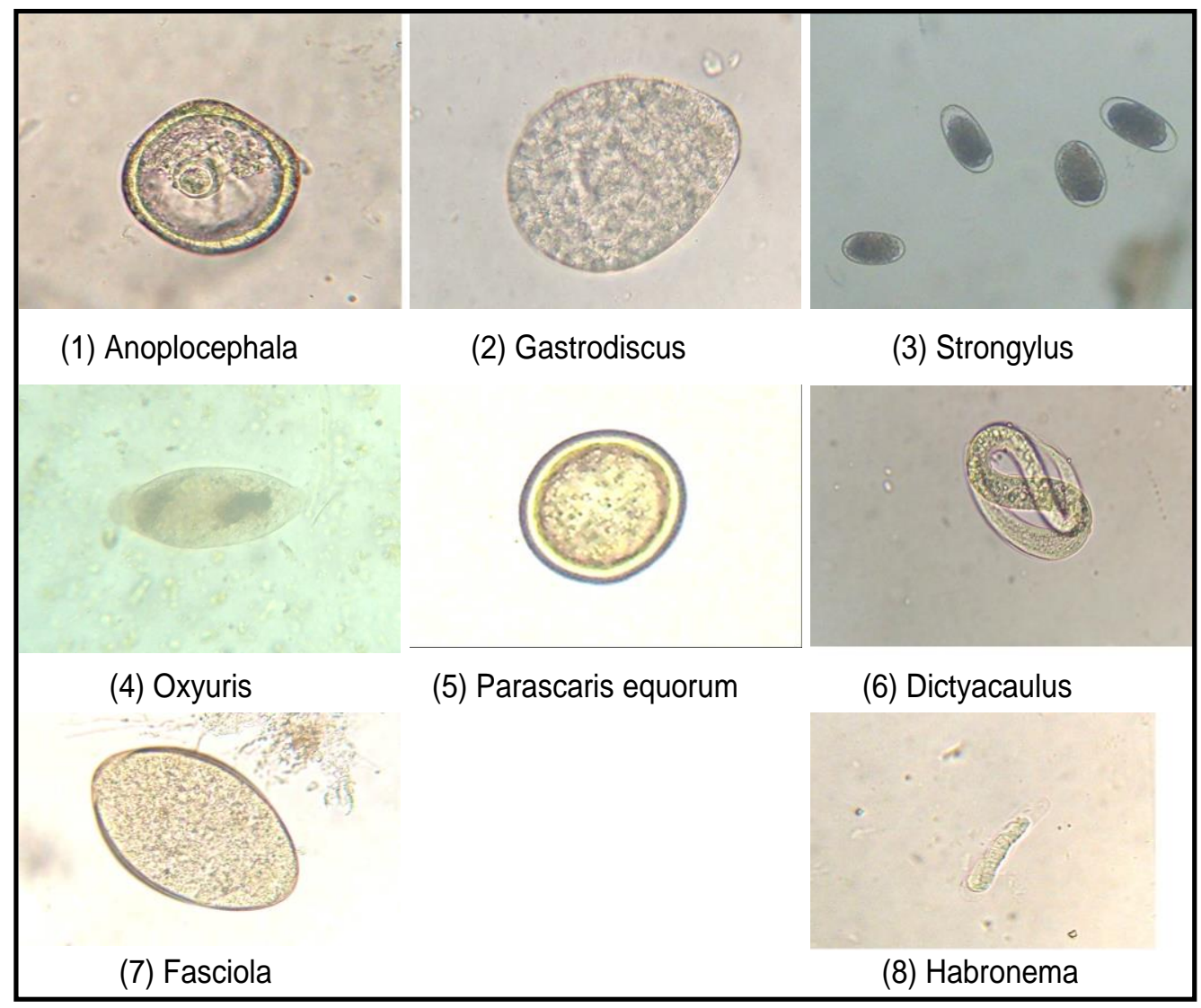

Fig. (1): Pictures of donkeys parasites 
A Coprological Survey Of Donkey Parasites In ...

Table (1): Prevalence of Gastrointestinal Parasites in donkeys

\begin{tabular}{|c|c|c|c|c|}
\hline Species & Total animals examined & Parasites & + & $\%$ \\
\hline \multirow[t]{8}{*}{ Donkey } & 236 & Parascaris equorum & 36 & 15.26 \\
\hline & & Strongylus spp. & 82 & 34.75 \\
\hline & & Oxyuris equi. & 29 & 12.29 \\
\hline & & Dictycaulus & 14 & 5.94 \\
\hline & & Habronema & 4 & 1.70 \\
\hline & & Anoplocephala spp. & 13 & 5.51 \\
\hline & & Gastrodiscus spp. & 9 & 3.82 \\
\hline & & Fasciola & 7 & 2.97 \\
\hline \multicolumn{3}{|c|}{ Total prevalence } & 194 & 82.21 \\
\hline
\end{tabular}

Table (2): Prevalence of gastrointestinal parasites in donkeys according to sex

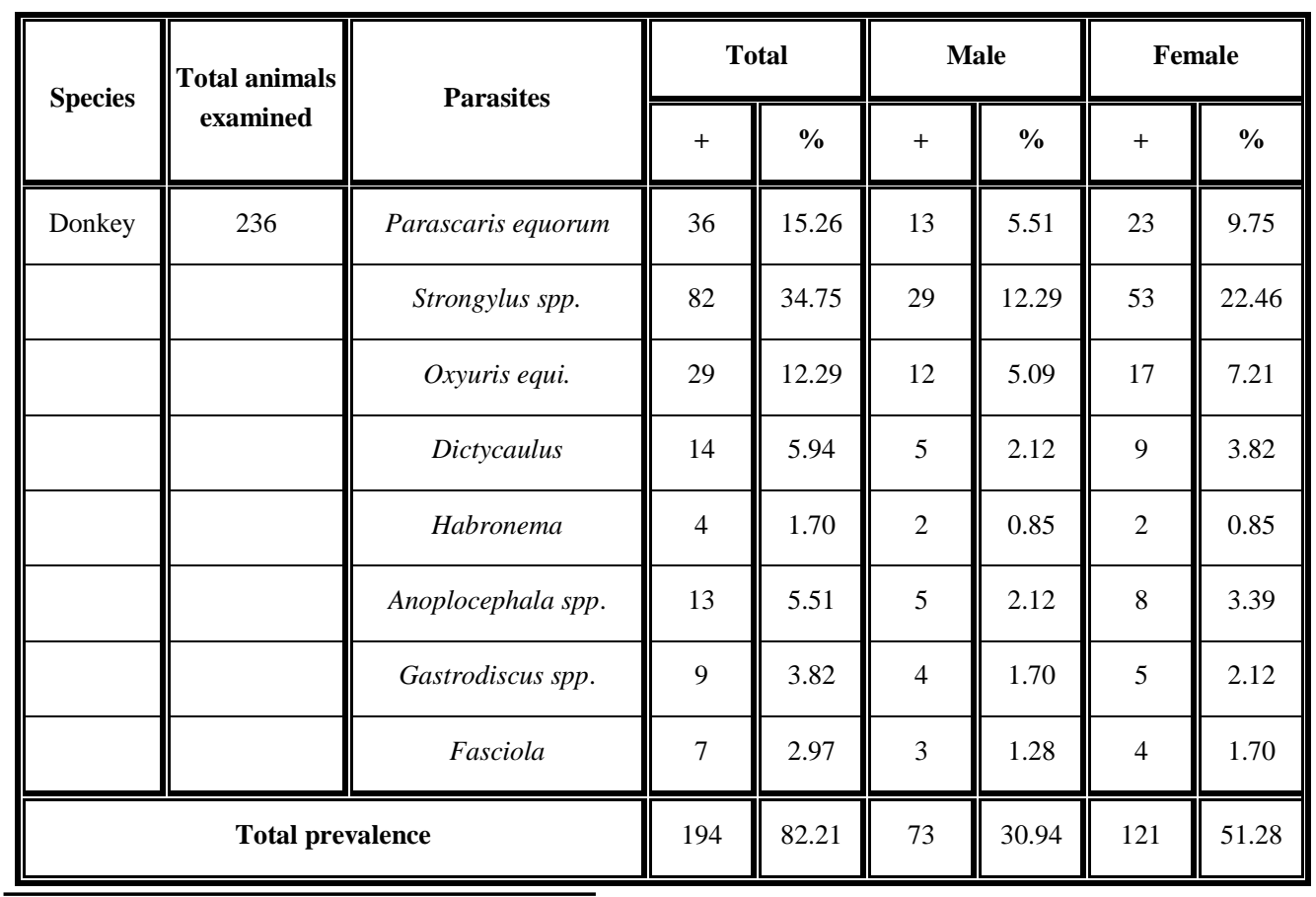

Kafrelsheikh Vet. Med. J. Vol. 8 No. 2 (2010) 
Table (3): Prevalence of gastrointestinal parasites in donkeys according to age.

\begin{tabular}{|c|c|c|c|c|c|c|c|c|}
\hline \multirow{2}{*}{ Species } & \multirow{2}{*}{$\begin{array}{c}\text { Total animals } \\
\text { examined }\end{array}$} & \multirow{2}{*}{ Parasites } & \multicolumn{2}{|c|}{ Total } & \multicolumn{2}{|c|}{ Up to 2 years } & \multicolumn{2}{|c|}{ 3-20 years } \\
\hline & & & + & $\%$ & + & $\%$ & + & $\%$ \\
\hline \multirow[t]{8}{*}{ Donkey } & 236 & Parascaris equorum & 36 & 15.26 & 13 & 5.51 & 22 & 9.75 \\
\hline & & Strongylus spp. & 82 & 34.75 & 29 & 12.29 & 51 & 22.46 \\
\hline & & Oxyuris equi. & 29 & 12.29 & 12 & 5.09 & 15 & 7.21 \\
\hline & & Dictycaulus & 14 & 5.94 & 6 & 2.12 & 8 & 3.82 \\
\hline & & Habronema & 4 & 1.70 & 3 & 0.85 & 3 & 0.85 \\
\hline & & Anoplocephala spp. & 13 & 5.51 & 6 & 2.12 & 6 & 3.39 \\
\hline & & Gastrodiscus spp. & 9 & 3.82 & 5 & 1.70 & 6 & 2.12 \\
\hline & & Fasciola & 7 & 2.97 & 4 & 1.28 & 5 & 1.70 \\
\hline \multicolumn{3}{|c|}{ Total prevalence } & 194 & 82.21 & 78 & 33.05 & 116 & 49.16 \\
\hline
\end{tabular}

Table (4): Prevalence of gastrointestinal parasites in donkeys regarding single infection and mixed infection.

\begin{tabular}{|c|c|c|c|c|c|c|c|}
\hline \multirow{3}{*}{ Species } & \multirow{3}{*}{$\begin{array}{c}\text { Total animals } \\
\text { examined }\end{array}$} & \multicolumn{6}{|c|}{ Type of parasites (\%) } \\
\hline & & \multicolumn{2}{|c|}{ Total prevalence } & \multicolumn{2}{|c|}{ Single infection } & \multicolumn{2}{|c|}{ Mixed infection } \\
\hline & & + & $\%$ & + & $\%$ & + & $\%$ \\
\hline Donkey & 236 & 82.21 & $(194 / 236)$ & 54.13 & $(105 / 194)$ & 45.87 & $(89 / 194)$ \\
\hline
\end{tabular}

$\overline{\text { Kafrelsheikh Vet. Med. J. Vol. } 8 \text { No. } 2 \text { (2010) }}$ 


\section{DISCUSSION}

Despite the considerable numbers and the neglected importance of donkeys in the developing countries economy, knowledge about the health problems affecting their welfare is not well known as far as we know for most parts of the world. Therefore, the objectives of this study were to determine spectrum of species and prevalence of major GIT parasites involved in donkeys. The microscopic fecal examination showed that helminthosis was an important health disease of donkeys in the study area. In our study, the rates for single infection $(54.13 \%)$ were more frequently found than the rates for mixed infection (45.87\%) (Table 4). Nearly similar results of mixed infections were detected in $54.8 \%$ of the donkeys of Dugda Bora District of Ethiopia (Ayele et al., 2006). These data are in accordance with those of other studies (Asano, 2004; Ragozo, 2002; and Ramirez-Barrios, 2004). The prevalence of Strongyle spp. was $34.75 \%$ which was similar to Seri et al., (2000) in Sudan who found Strongylus sp. (35.8\%) and lower than the work of Yoseph et al., (2001) in Ethiopia who have reported $100 \%$ in donkeys. Similar results were obtained earlier by Vercruysse et al., (1986) from Burkina Faso with a prevalence of $100 \%$ for Strongylus vulgaris. The prevalence of Parascaris equorum was $15.26 \%$ which is in agreements with that of Yoseph et al., (2001) and Fikru et al., (2005) have reported 15.7\% and $17.3 \%$, and nearly similar to Seri et al., (2000) in Sudan who found Parascaris equorum (10.7\%) and lower than that of Mulate, (2005) who reported $43.8 \%$ in Ethiopia. Oxyuris equi with prevalence rate of $12.29 \%$ was very low compared with the work of Yoseph et al., (2001) who 
reported $32.4 \%$ in Ethiopia. The low prevalence in this study might be due to obtaining samples from rectum and not performing perineal tape method which is recommended for $O$. equi as the gravid females lay eggs in perineal region. The prevalence of Anaplocephala spp was 5.51\% .This low prevalence could be assumed due to the seasonality of Orbited mites intermediate host (Soulsby, 1982). Similar results were reported in the survey of helminthosis conducted in the central high lands of Ethiopia (Yoseph et al., 2001). Lower prevalence (3.82\%) of Paramphistomid (Gastrodiscus spp.) was recorded in the present study compared to other reports in Ethiopia (Yoseph et al., 2001; Mulate, 2005). This lower prevalence might be due to the differences in ecological conditions for the development of intermediate snails and the parasite. The maintenance of high infection rate of parasitic helminthes in the study area might be associated with lack of any regular parasitic helminthes intervention program and the management system in the area where many donkeys were allowed to graze together on small plots of land through out the year which facilitates contamination between animals. Therefore in conclusion, This study revealed that working donkeys in the study area are infected with a range of helminthes and arthropod larvae, which are representatives of the important pathogenic parasites found in equids worldwide which are affecting the health and welfare of donkeys in the study area. Government or non profitable development agencies should include donkeys in their priority lists of research and develop sustainable integrated diseases prevention and control programs that are practical for developing communities. 


\section{REFERENCES}

- Asano, K. (2004): Prevalence of dogs with intestinal parasites em Tochigi, Japan em 1979, 1991 and 2002. Vet. Parasitol., 120(3): 243248.

- Ayele, G.; Feseha, G.; Bojia, E. and Joe, A. (2006): Prevalence of gastro-intestinal parasites of donkeys in Dugda Bora District, Ethiopia. Livestock Research for Rural Development 18 (10).

- El-Seify, M.A.; Ahmed, Z. G.; Derhalli, F. S. and Abdel Gawad, A. (1985): Studies on some helminth parasites of equines. Vet. Med. J. 33(2): 289-299.

- El-Seify, M.A.; Harfoush, M. A. and El-Shahawy, I. S. (2010): Biological aspects on Dctyocaulus Arnfieldi. J. Egypt. Soc. Parasitol., 40(2), 395-400.

- El-Seify, M.A. and Hasslinger, M. A. (1991). Natural infection of equids with Dictycaulus arnfieldi in Egypt. J. Egypt. Vet. Med. Assoc. 51 No. Land 2,519-528.

- Eysker, M. and Pandey, V. S. (1989): Small strongyle infections in donkeys from highveld in Zimbabwe. Vet. Parasitol., 30(40): 345-349.

- Getachew, M.; Trawford, A.; Feseha, G. and Reid, S. W. (2010): Gastrointestinal parasites of working donkeys of Ethiopia. Trop. Anim. Health Prod., 42(1):27-33. 
- Fikru, R.; Reta, D. and Bizunesh, M. (2005): Prevalence of equine gastrointestinal parasites in western high lands of Oromia, Ethiopia. Bulletin of Animal Health and Production in Africa. Pp. 161-166.

- Gebre Wold, A.; Tegegn, A. and Yami, A. (2004): Research needs of donkey utilization in Ethiopia. In: Fielding and Starkey P (editors). Donkeys, People and Development. A resource book of the animal traction network for eastern and Southern Africa (ATNESA), Technical center for agriculture and rural cooperation (CTA), Wageningen, The Netherlands, pp. 77-81, ISBN 92-9081-219-2.

- Hasslinger, M. A.; Ashmawy, K. I. and El-Seify, M.A. (1996): Remarks to Gastrodiscus aegyptiacus (Cobbald, 1976), an equine parasite. VII European Multicolloquium of Parasitology (E.M.O.P.VII), Parma, Italy, 2-6 Sept. 1996.

- Hasslinger, M. A. and El-Seify, M.A. (1996): A study on the infestation with paramphistomatidae in equides in Egypt. BerlMunch.Tieraztl.Wschr. 159,224-226.

- Marshall, K. and Ali, Z. (2004): In: Fielding and Starkey P (editors). Donkeys, People and Development. A resource book of the animal traction network for eastern and Southern Africa (ATNESA). Technical center for agriculture and rural cooperation (CTA), pp. 7781, Wageningen, The Netherlands,. ISBN 92-9081-219-2. 
- Matthee, S.; Milne, S. A. and Krecek, R. C. (2000): Prevalence and biodiversity of helminth parasites in donkeys from South Africa. J. Parasitol., 86 (4): 756-762.

- Mulate, B. (2005): Preliminary study on helminthosis of Equines in south and north Wollo Zones. J. Vet. Assoc., 9 (2): 25-37.

- Pandey, V. S.; Ouhelli, H. and Verhulst, A. (1992): Epidemiological observations on stomach worms of donkeys in Morocco. Vet. Res Commun., 16 (40): 273-279.

- Pearson, R. A.; Nengomasha, E. and Krecek, R. C. (1999): The challenges in using donkeys for work in Africa. In: Starkey PH, Kaumbutho P (editors). Meeting the Challenges of Animal Traction . A resource book of the Animal Traction Network for Eastern and Southern Africa (ATNESA), pp. 190-198, Harare, Zimbabwe. Intermediate Technology Publications, London.

- Ragozo, A. M. A. (2002): Ocorrência de parasitos gastrintestinais em fezes de gatos da cidade de São Paulo e Guarulhos. Brazilian Journal of Veterinary Research and Animal Science, 39( 1/6): 244-246.

- Ramirez-Barrios, $\boldsymbol{R}$. A. (2004): Prevalence of intestinal parasites in dogs under Veterinary care in Maracaibo, Venezuela. Vet. Parasitol., 121 (1-2): 11-20. 
- Ricci, M. and Sabatini, A. (1992): Parasitic helminthes of the cecum and colon of equidae in Italy. Parasitologia, 34 (1-3):53-60.

- Seri, H. I.; Hassan, T.; Salih, M. M. and Abakar, A. D. (2000): A survey of gastrointestinal nematodes of donkeys (Equus asinus) in Khartoum State, Sudan. Journal of Animal and Veterinary Advances.

- Soulsby, E., (1982): Helminths, Arthropds and Protozoa of Domestic Animals. 7th edition, 790p. Balliere Tindall, 1st Annes Road, East bourne, East Sussex BN21.

- Urquhart, G. M., Armour, J., Duncan, J. L., Dunn, A. M., and Jennings, F. W., (1996): Veterinary Parasitology, 2nd ed.307p. Black well Science limited, London.

- Vercruysse, J.,; Harris, E. A.; Kabret, Y. Y.; Gibson, D. I. and Pangui, L. J. (1986): Gastro-intestinal helminthes of donkeys in Burkina Faso. Z Parasitenkd, 72 (6): 821-825.

- Yamaguti, S. (1959): Systema Helminthum, Vol II. The cestodes of vertebrates. Inter Science, New York.

- Yoseph, S.; Feseha, G. and Abebe, W. (2001): Survey on helminthosis of equines in Wonchi, Ethiopia. Journal of the Ethiopian Veterinary Association, 5: 47-61. 


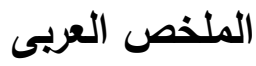

أجريت هذه الدراسة خلال الفترة من شهر يناير الى اغسطس2010 فى القرى المحبطة بمدينة

المحلة الكبرى بمحافظة الغربية حيث المجتمعات ماهولة. تم فحص عدد 236حمار (132 ذكر و 104 انتى) وكان الاختبار عشوائمن المناطق الماهولة حيث تم عمل فحص نوعى لعينات البرازللتعرف على اهم الطفيليات والتى تمثل خطورة طفيلية. تم تقسيم الحمير حسب العمر الى مجموعتان (تحت عمر سنتان وصنفت المجموعة الصغيرة عمريا ومن عمر سنتان الى عشر سنوات وصنفت المجموعة الكبيرة عمريـا.تم عمل مقارنـات بين المجموعات العمريـة المختلفة وايضـا حسب الجنس. كانت نسبة الاصـابة بالطفيليات بنسبة 82.21\% (194/236). كانت الاصـابة بطفيل واحـد فى الحمير بنسبة 54.13\% (194/105) بينمـا الاصـابة بـاكثر مـن طفيـل كانـت بنسبة 45.87\% (89/194). كانت النيماتودا تمثل اعلى نسبة اصـابة بنسبة 69.92\% (165/236). كانت الاسترونجيلس اعلى نسبة اصـابة بنسبة 34.75\% (82/236) ويليها الباراسكارس ايكويرم 15.26\% (36/236) ثم الاكسيورس ايكواى 12.29\% (29/236) ثم الديكتيوكولاس 5ز 94\% (14/236) والهابرونيما 1.7\% (14/236) بالترتيب. كانت الديدان الثريطية مثل الانوبلوسيفلا بنسبة 5.51\% (13/236) بينما كانت التريماتودا مثل الجاستروديسكاس بنسبة 3.82\% (9/236) والفاشيولا 2.97\% (7/236) بالترتيب.حسب الجنس كانت نسبة الاصابة فى الاناث 51.28\% (121/236) اعلى منها فى الذكور 30.94\% (73/236). حسب العمر كانت الاصابة فى الاعمار الصغيرة 33.05\% (87/236) اقل منها فى الاعمار الكبيرة \%49.16 (116/236). اعطيت التوصيات حسب النتائج. 